\title{
Kelayakan dan Strategi Pengembangan Kemitraan KUB Petani Lidah Buaya di Kecamatan Beji, Depok
}

\author{
Feasibility and Business Development Strategy Partnership KUB
} Aloe Vera Farmers in Beji Subdistrict, Depok

\author{
Puty Yousnelly $^{\star 1}$, Nora H. Pandjaitan ${ }^{\# 2}$ dan Budi Purwanto ${ }^{\# 3}$ \\ ${ }^{* 1}$ PT Ghalia Indonesia \\ Jl. Rancamaya KM 1 No. 47 Ciawi, Bogor \\ ${ }^{2}$ Departemen Teknik Sipil dan Lingkungan, Fakultas Teknologi Pertanian, Institut Pertanian Bogor \\ ${ }^{3}$ Departemen Manajemen, Fakultas Ekonomi dan Manajemen, Institut Pertanian Bogor \\ \#JI. Kamper, Kampus IPB Darmaga, Bogor 16680
}

\begin{abstract}
ABSTRAK
Keberhasilan Lidah Buaya sebagai komoditas bisnis pada pola kemitraan, seperti antara PT Kavera Biotech dan kelompok usaha bersama (KUB) petani Lidah Buaya di Kecamatan Beji, Depok memerlukan evaluasi yang cermat. Tujuan penelitian (1) mengkaji bentuk usaha kemitraan, (2) menganalisis kelayakan usaha, serta (3) menganalisis strategi pengembangan usaha. Pengumpulan data dilakukan melalui observasi, wawancara, serta menyebarkan kuesioner. Pemilihan lokasi dilakukan secara sengaja dengan pertimbangan lokasi tersebut merupakan percontohan untuk budi daya Lidah Buaya. Kelayakan usaha dinilai dengan metode Payback Periode (PBP), Net Present Value (NPV), Benefit/Cost Ratio (BCR), Internal Rate of Return (IRR), dan Break Event Point (BEP). Analisis strategi pengembangan usaha menggunakan Tahap Input (External Factor Evaluation atau EFE dan Internal Factor Evaluation atau IFE), Tahap perpaduan (Strengths, Weaknesses, Opportunities and Threats atau SWOT dan Internal-External atau IE), serta Tahap Keputusan (Quantitative Strategic Planning Matrix atau QSPM). Hasil analisis menunjukkan usaha Lidah Buaya dengan pola kemitraan berdasarkan Analisis I layak dilaksanakan di 6 KUB, sedangkan berdasarkan Analisis II layak dilaksanakan di 5 KUB. Analisis I pada petani yang memanfaatkan lahan pekarangan rumah, atau di pot bahwa usaha ini layak dilaksanakan, sedangkan dengan Analisis II untuk petani di KUB Tanah Baru dan Kemiri Muka usaha ini tidak layak dilaksanakan. Sementara itu, pemanfaatan lahan terlantar di KUB Pondok Cina dan Tanah Baru berdasarkan Analisis I dan II usaha ini layak dilaksanakan. Petani yang memanfaatkan lahan pekarangan rumah atau di pot dengan penanaman skala kecil $(<100$ tanaman), skala sedang (100-199 tanaman), dan skala besar (200-399 tanaman), serta petani yang berusaha di lahan terlantar dengan penanaman skala sempit (300-399 tanaman), skala sedang (400-499 tanaman), dan skala luas (> 500 tanaman) berdasarkan Analisis I dan II layak dilaksanakan. Hasil analisis strategi pengembangan usaha yang terbaik adalah perlunya meningkatkan produktivitas dalam memanfaatkan permintaan bahan baku Lidah Buaya yang semakin meningkat. Implementasi strategi dilakukan dengan mengembangkan usaha tani dan pendukungnya secara efektif dan efisien.
\end{abstract}

Kata kunci: kelayakan usaha, kelompok usaha bersama, Lidah Buaya, strategi kemitraan

\section{ABSTRACT}

The success of aloe vera as business commodity in co-partnership pattern, like that between PT Kavera Biotech and the collective work cluster (KUB) of aloe vera farmers in Kecamatan Beji, Depok, needs an accurate evaluation. The objective of this research were to (1) investigate the co-partnership business, (2) analyze the feasibility, and (3) analyze the development strategy. The data were collected by observation, interview, and questionnaire. The location selection was done purposively based on the consideration that the location had been used as sampling for aloe vera cultivation. The feasibility of business was valued using the methods of PBP, NPV, BCR, IRR, and BEP. Analysis of enterprise development strategy using the Input Stage (EFE and IFE), Matching Stage (SWOT and IE), and Decision Stage (QSPM). The result of this study showed that the aloe vera business with co-partnership pattern based on Analysis I was feasible to be managed in $6 \mathrm{KUBs}$; while the one based on Analysis II was feasible to be managed in $5 \mathrm{KUBs}$. Analysis I on the farmers with house-yard cultivation field or pot cultivation resulted that it was feasible to be managed, while the Analysis II on the farmers in KUB Tanah Baru and Kemiri Muka resulted that they were not feasible to be managed. In the meantime, the aloe vera cultivation in abandon field in KUB Pondok Cina and Tanah Baru were feasible to be managed based on Analysis I and II. The farmers with house-yard cultivation field or pot cultivation in small scale $(<100$

\footnotetext{
Korespondensi:

Jl. Rancamaya KM 1 No. 47 Ciawi, Bogor; e-mail: pyn_okti@yahoo.com
} 
plants), middle scale (100-199 plants), and big scale (200-399 plants) cultivation and the aloe vera cultivation in abandon field with small scale (300-399 plants), middle scale (400-499 plants), and big scale ( $>500$ plants) on Analysis I and II that it was feasible to be managed. The best result of the development strategies is the need to increase the productivity in utilizing the increasing demand of aloe vera materials. The implementation of the strategy is performed by advancing the work cluster along with its supporter effectively and efficiently.

Key words: aloe vera, collective work cluster (KUB), co-partnership strategy, feasibility study

\section{PENDAHULUAN}

Sektor pertanian tetap dipandang sebagai sektor strategis dalam pembangunan nasional. Kebijaksanaan pembangunan pertanian saat ini adalah meletakkan masyarakat sebagai pelaku utama dalam pembangunan. Peran pemerintah yang sebelumnya sangat dominan, saat ini berubah menjadi fasilitator, stimulator, atau promotor dalam pembangunan pertanian. Pembangunan pertanian lebih mengandalkan kreativitas rakyat di setiap daerah (Sumodiningrat, 2000; Syafa'at et al, 2005).

Di sisi lain, pengembangan wilayah selalu memperhatikan potensi dan kondisi sumber daya lokal dalam kaitan sebagai aset ekonomi suatu kawasan. Pengembangan kapasitas masyarakat merupakan upaya untuk meningkatkan pendapatan masyarakat lokal melalui kegiatan ekonomi produktif berbasis produk unggulan wilayah (Sumodiningrat, 2000). Oleh karena itu, upaya pengembangan UKM terutama yang banyak mengandalkan sumber daya lokal dan didukung oleh adanya institusi yang handal merupakan tumpuan dalam upaya memperbaiki kondisi sosial dan ekonomi negara di masa mendatang (Adi, 2007; Hubeis, 2009; Sulaeman, 2009.

Pada umumnya, kendala yang dihadapi oleh UKM di Indonesia dalam mengemban usahanya masih merupakan kendala klasik, seperti keterbatasan akses terhadap sumber pendanaan dan pemasaran. Namun demikian, di balik kesulitan dana bagi pengembangan UKM, terutama UKM pemula, ternyata banyak di antaranya yang produk, atau komoditasnya mempunyai keunggulan komparatif. Salah satu komoditas yang dimaksud adalah Lidah Buaya (Aloe vera L.) (Sulaeman, 2009).

Tanaman Lidah Buaya dapat dijadikan sebagai komoditas unggulan mengingat manfaat dan nilai ekonomis cukup tinggi. Hingga saat ini sebagian besar tanaman Lidah Buaya diolah menjadi makanan dan minuman. Makanan berserat dari lidah buaya dengan menggunakan berbagai jenis gula mempunyai berat dan kenampakan morfologis serta kandungan gizi yang baik untuk kesehatan (Asngad, 2008). Kadar serat yang diperoleh pada gel lidah buaya sebagai bahan baku 0,15\% (Ramadhia, 2012). Selain itu, tanaman Lidah Buaya diekspor dalam bentuk pelepah segar ke luar negeri, seperti ke Singapura, Malaysia, dan Brunei Darussalam. Hasil olahan yang terbatas dan ekspor dalam bentuk bahan baku hanya memberikan sedikit nilai tambah. Nilai tambah yang lebih besar akan diperoleh jika tanaman Lidah Buaya diolah menjadi produk yang dibutuhkan industri sebagai bahan baku industri lanjutan (Sulaeman, 2009).

Sebagai bahan baku, tanaman Lidah Buaya tidak dapat digunakan secara langsung dalam bentuk pelepah segar, tetapi harus diolah dahulu menjadi gel (aloe gel), atau tepung (aloe powder). Rasio kebutuhan pelepah segar terhadap produk olahan, seperti tepung Lidah Buaya sangat besar, bahkan perbandingan untuk tepung Lidah Buaya dengan mutu sangat baik dapat mencapai $150: 1$. Hal tersebut menunjukkan bahwa dari sisi bisnis, komoditas tersebut sangat berpotensi untuk dikembangkan, sehingga dapat meningkatkan pendapatan petani dan pelaku industri pengolahannya, yang akhirnya akan berdampak positif pada peningkatan ekonomi wilayah. Oleh karena itu, apabila komoditas tersebut akan dikembangkan usahanya, maka sebaiknya industri yang memproduksi gel, ataupun tepung harus memiliki kontinuitas ketersediaan bahan baku (pelepah segar). Kondisi tersebut dapat tercapai jika industri dan petani Lidah Buaya terkait secara langsung dalam suatu klaster bisnis (Sulaeman, 2009).

PT Kavera Biotech merupakan salah satu industri pengolahan Lidah Buaya yang di antaranya memproduksi minuman sehat (berserat) Lidah Buaya. Pengembangan usaha dari perusahaan tersebut ternyata membutuhkan bahan baku pelepah Lidah Buaya yang lebih banyak dengan standar mutu pelepah yang telah ditentukan perusahaan serta adanya kontinuitas bahan baku. Oleh karena itu, saat ini perusahaan tersebut dalam memenuhi bahan bakunya bermitra dengan petani Lidah Buaya (mitra binaan plasma) yang membentuk Kelompok Usaha Bersama (KUB). KUB tersebut beranggotakan petani Lidah Buaya dari beberapa daerah di Depok. Salah satunya di Kecamatan Beji, Depok yang telah dibentuk mulai pada tahun 2007 (Nurtiyani, 2008).

Keberhasilan suatu usaha seperti komoditas Lidah Buaya dengan pola kemitraan, seperti yang dilakukan oleh PT Kavera Biotech dengan KUB petani lidah buaya di Kecamatan Beji, Depok, memerlukan adanya evaluasi kemitraan, kelayakan, dan perencanaan pengembangan usaha yang baik. Kemitraan tersebut baru berjalan beberapa tahun, sehingga perlu diketahui kelayakan usaha dari para petani dan KUB-nya.

Tujuan kajian adalah (1) Mengidentifikasi bentuk usaha kemitraan antara petani dan industri pengolahan Lidah Buaya, (2) Menganalisis 
kelayakan usaha dari sisi petani dan KUB, dan (3) Menganalisis strategi pengembangan usaha.

\section{METODOLOGI}

Kegiatan ini dilaksanakan di daerah penanaman Lidah Buaya dan industri pengolahan Lidah Buaya di wilayah Kecamatan Beji, Depok, Jawa Barat. Pemilihan lokasi dilakukan secara sengaja (purposive) dengan pertimbangan bahwa lokasi tersebut merupakan lahan percontohan untuk budidaya Lidah Buaya, baik di lahan pekarangan rumah maupun lahan terlantar yang tidak produktif.

Kelembagaan tani yang menjadi subyek penelitian ini adalah Kelompok Usaha Bersama (KUB) Petani Lidah Buaya yang berlokasi di Kecamatan Beji, Depok, Jawa Barat. KUB Petani Lidah Buaya terdiri atas 6 kelompok tani di wilayah Kelurahan Pondok Cina, Kelurahan Kukusan, Kelurahan Beji Timur, Kelurahan Tanah Baru, Kelurahan Beji, dan Kelurahan Kemiri Muka. Saat ini anggota KUB di Kecamatan Beji, Depok ada 29 petani Lidah Buaya.

Penelitian dilakukan juga terhadap perusahaan mitra (PT Kavera Biotech) yang terletak di lingkungan kampus Universitas Indonesia (Laboratorium Parangtopo FMIPA UI Depok). Perusahaan tersebut telah melakukan kemitraan dengan petani Lidah Buaya yang tergabung dalam kelembagaan KUB Petani Lidah Buaya Kecamatan Beji, Depok sejak tahun 2008

Pengambilan data primer dan sekunder dilakukan dari bulan April-Juli 2009, baik di KUB Petani Lidah Buaya, Koperasi Tani Aloe Vera, PT Kavera Biotech, maupun di Pusat Sinergi Riset dan Bisnis (PSRB), serta studi kepustakaan.

Data primer diperoleh melalui pengamatan langsung (observasi), wawancara (interview), serta pengisian kuesioner kepada koordinator petani Lidah Buaya (mitra binaan plasma KUB) dan tenaga pendamping petani Lidah Buaya dari Kecamatan Beji Depok, pengurus Koperasi Tani Aloe Vera, pimpinan PT Kavera Biotech, serta pimpinan Pusat Sinergi Riset dan Bisnis (PSRB). Analisis kemitraan inti plasma menitikberatkan pada aspek teknis produksi dan aspek pasar yang dilihat dari kerja samanya, jangka waktu kemitraan, hak dan kewajiban masing-masing, serta rencana pengembangan dari kemitraan. Analisis kelayakan finansial pada petani dan KUB dengan metode Payback Period (PBP), Net Present Value (NPV), Benefit Cost Ratio (BCR), Internal Rate of Return (IRR), dan Break Event Point (BEP).

Analisis strategi pengembangan usaha dilakukan dengan tahapan (David, 2005):

1. Tahap Input (Input Stage), digunakan model Matriks Evaluasi Faktor Eksternal (EFE Matrix) dan Matriks Evaluasi Faktor Internal (IFE Matrix).
2. Tahap Analisis (Matching Stage), digunakan Matriks Internal-Eksternal (IE) dan Strength, Weaknesses, Opportunies and Threath (SWOT).

3. Tahap Keputusan (Decision Stage), digunakan Quantitative Strategic Planning Matrix (QSPM)

4. Selain itu dilakukan analisis EFE dan IFE, analisis SWOT dan IE, serta analisis QSPM. Keseluruhan hasil analisis nantinya merupakan masukan untuk pengembangan usaha kemitraan KUB petani Lidah Buaya di Kecamatan Beji, Depok.

\section{HASIL DAN PEMBAHASAN}

\section{Kajian Kemitraan antara KUB Petani Lidah Buaya dan PT Kavera Biotech}

\section{Usaha Lidah Buaya dan Kemitraannya}

Melalui tahapan seleksi dan uji coba produk di lingkungan Kampus Universitas Indonesia (UI) Depok terhadap beberapa jenis tumbuhan yang kaya akan nutrisi, diperoleh beberapa tumbuhan dan produk olahannya yang paling menjanjikan untuk dipasarkan secara luas. Di antara produk yang berhasil dikembangkan dan meraih banyak minat adalah produk minuman sehat Lidah Buaya yang berasal dari tanaman Lidah Buaya (Aloe vera var. chinensis). Untuk memproduksi minuman tersebut, PT Kavera Biotech telah bermitra dengan petani yang tersebar di Pulau Jawa, di antaranya di Parung, Bogor, Sukabumi, Cikampek, Semarang, dan Malang.

Beberapa indikator sukses yang dicapai dari hasil penelitian yang berkesinambungan tersebut adalah diperolehnya HaKI melalui paten proses ID 0000429 S pada tahun 2003, serta pengembangan industri pengolahan dan pemasaran melalui PT Kavera Biotech dengan merek Kavera dan berbagai co-branding. Keunggulan produk yang diproses sesuai paten tersebut adalah kemampuannya mempertahankan kandungan MPS (mukopolisakarida), yaitu suatu nutrisi tumbuhan yang sangat bermanfaat bagi kesehatan manusia, di antaranya dapat meningkatkan fungsi sistem kekebalan dalam sel dan efektif menghilangkan racun. Hasil kajian Ramadhia et al. (2012), diketahui adanya aktivitas penangkapan radikal bebas yang terdapat pada gel lidah buaya sebesar 69,26\%. Data ini didukung hasil penelitian Padmarsari et al. (2006), bahwa aktivitas penangkapan radikal bebas pada gel lidah buaya sebesar 68,33\%. Kandungan lidah buaya sebagian besar adalah air $99,5 \%$ dengan total padatan terlarut hanya $0,49 \%$, lemak $0,67 \%$, karbohidrat $0,043 \%$, protein $0,038 \%$, vitamin $A$ 4,594\% IU, dan vitamin C 3,476 mg (Furnawanthi, 2002),

Dalam memproduksi produk baru berupa tepung Lidah Buaya (aloe powder) dan minuman instan (effervescent) juga diperlukan bahan baku yang lebih banyak lagi, sehingga terjadi permintaan (supply) bahan baku pelepah Lidah 
Buaya. Untuk meningkatkan pasokan pelepah Lidah Buaya, pada tahun 2008 PT Kavera Biotech bersama PSRB melakukan suatu program yang melibatkan masyarakat, yaitu pemberdayaan masyarakat untuk melakukan budi daya tanaman Lidah Buaya melalui sistem kemitraan usaha pertanian.

\section{Pelaksanaan Kemitraan}

PSRB dan PT Kavera Biotech mensosialisasikan penawaran untuk penanaman Lidah Buaya ke warga yang berminat. Pada awalnya ditawarkan dulu produk minuman Lidah Buaya dengan segala manfaat dari tanaman Lidah Buaya itu. Selanjutnya, warga ditawarkan untuk mengembangkan dan menanam Lidah Buaya di pekarangan rumah, seperti di pot, atau lingkungan masing-masing karena tanaman tersebut tidak memerlukan lahan khusus dan perawatan yang sulit. Selain itu, lidah buaya termasuk tanaman yang efisien dalam penggunaan air serta dapat tumbuh di daerah basah dan kering (Wahjono dan Koesnandar 2002). Warga yang tertarik dan berminat untuk menanam Lidah Buaya diharapkan dapat melaksanakan dengan serius dan bertanggung jawab sehingga dapat benarbenar menikmati manfaatnya nanti. Dalam hal pengembangan budi daya Lidah Buaya, yang berperan mendata warga atau petani Lidah Buaya tersebut adalah koperasi (KSU Tani Aloe Vera) melalui tenaga pendamping petaninya. Pendataan dimulai dari pembibitan sampai panen bibit dan pelepah Lidah Buaya.

Wilayah budi daya tanaman Lidah Buaya diutamakan yang dekat dengan industri pengolahan Lidah Buaya (PT Kavera Biotech) di Depok, seperti Kecamatan Beji, Kecamatan Limo, Kecamatan Cimanggis, Kampus UI Depok, Kecamatan Bojong Gede, dan Cibubur. Pengamatan dilakukan di wilayah Kecamatan Beji, Depok karena lokasi tersebut merupakan percontohan budi daya Lidah Buaya di lahan pekarangan rumah, ataupun lahan terlantar.

Rencana jangka pendek usaha budi daya Lidah Buaya di Kecamatan Beji, Depok adalah pengembangan budi daya Lidah Buaya yang dilakukan dengan penanaman Lidah Buaya di setiap pekarangan rumah dan tanah terlantar. Hal tersebut dalam rangka penghijauan dan pemanfaatan sampah organik yang dapat dibuat dalam skala rumah tangga sehingga lingkungan menjadi hijau dan bersih. Menurut Sasli et al (2008), pupuk organik terfermentasi mampu meningkatkan pertumbuhan yang lebih baik pada tanaman lidah buaya. Selain itu, membuat kelompok tani (KUB Petani Lidah Buaya) dapat terkontrol, sehingga mempermudah kinerja antara koperasi dan kelompok tani serta dapat mengevaluasi hasil produk berupa bibit dan pelepah Lidah Buaya.

Rencana jangka menengah usaha budidaya Lidah Buaya di Kecamatan Beji, Depok adalah pemanfaatan tanaman Lidah Buaya. Petani diharapkan dapat mengetahui bahwa banyak manfaat yang diperoleh dari menanam tanaman Lidah Buaya. Pelepah Lidah Buaya dapat dimanfaatkan untuk masalah internal di rumah tangga, di antaranya untuk menyembuhkan luka, ataupun luka bakar, obat sembelit, obat tukak lambung, menjaga stamina tubuh, obat jerawat, menyuburkan rambut, dan untuk bahan makanan.

Rencana jangka panjang usaha budi daya Lidah Buaya di Kecamatan Beji, Depok adalah pembentukan skala industri rumah tangga (IRT) sehingga dihasilkan suatu produk terstandardisasi sesuai riset, seperti minuman kesehatan dan kapsul. IRT tersebut dapat dikembangkan menjadi tolok ukur ke tiap wilayah lainnya di Indonesia.

Program pemberdayaan masyarakat dalam budi daya tanaman Lidah Buaya di Depok dilakukan dengan pola inti plasma. Kemitraan tersebut adalah kerja sama usaha antara perusahaan mitra dan kelompok mitra di bidang usaha pertanian. Dalam hal ini, perusahaan mitra (inti) adalah PT Kavera Biotech dan kelompok mitra (plasma) adalah KUB Petani Lidah Buaya.

Menurut Hafsah (2000) kemitraan dengan pola inti plasma, UB sebagai inti membina dan mengembangkan UMKM yang menjadi plasmanya dalam penyediaan dan penyiapan lahan; penyediaan sarana produksi; pemberian bimbingan teknis produksi dan manajemen usaha; perolehan, penguasaan, dan peningkatan teknologi yang diperlukan; pembiayaan; pemasaran; penjaminan; pemberian informasi; dan pemberian bantuan lain yang diperlukan bagi peningkatan efisiensi, produktivitas, dan wawasan usaha.

Usaha tanaman Lidah Buaya dilaksanakan oleh petani, baik di lahan pekarangan rumah miliknya maupun di lahan terlantar, mulai dari pembibitan, budi daya, sampai pemasarannya. Hasil panen bibit dan pelepah Lidah Buaya dikumpulkan pada koordinator kelompok tani (KUB Petani Lidah Buaya) yang kemudian akan menawarkan pelepah Lidah Buaya tersebut ke industri pengolahan Lidah Buaya (PT Kavera Biotech) melalui koperasi (KSU Tani Aloe Vera). Hal tersebut tidak terlepas dari permintaan masyarakat atas produk minuman Lidah Buaya yang semakin meningkat, sehingga jumlah pelepah Lidah Buaya yang dibutuhkan oleh industri pengolahan Lidah Buaya semakin meningkat pula. Selain itu, industri pengolahan Lidah Buaya juga menawarkan beragam produk ke masyarakat, sehingga terjadi perputaran ekonomi di masyarakat.

Usaha kemitraan antara petani (KUB Petani Lidah Buaya) dan industri pengolahan Lidah Buaya (PT Kavera Biotech) di Depok dapat dibuat suatu model kluster bisnis usaha Lidah Buaya seperti digambarkan pada Gambar 1.

Usaha Lidah Buaya di Depok yang memproduksi minuman Lidah Buaya berupa Nata de aloe dan Jus atau energy drink, tepung Lidah Buaya (aloe powder), dan minuman instan (effervescent) bentuk granul, sebagaimana usaha 
berbasis hasil pertanian lainnya memerlukan keterkaitan yang erat antara hulu (up stream) dan hilir (down stream). Di hulu petani memiliki keahlian dan kemauan dalam berproduksi, tetapi terdapat keterbatasan dalam mengakses pasar dan teknologi; sedangkan di hilir industri pengolahan memiliki kekuatan dalam hal teknologi dan akses pasar, tetapi membutuhkan kontinuitas dalam ketersediaan bahan baku.

Kebutuhan yang berbeda antara hulu dan hilir dapat dijembatani oleh suatu lembaga (Koperasi). Lembaga tersebut di tingkat hulu diharapkan bertindak mendampingi, membimbing, dan memonitor kegiatan yang berjalan. Pada tingkat hilir, lembaga berfungsi sebagai mediator yang memberikan masukan dan informasi tentang ketersediaan produk di tingkat hilir

\section{Manfaat Kemitraan}

Kemitraan antara petani (plasma KUB) dan industri pengolahan (inti) dari usaha Lidah Buaya di Depok akan berhasil bila saling bekerja sama sesuai dengan aturan yang telah disepakati. Pelaksanaan kemitraan antara KUB Petani Lidah Buaya dan PT Kavera Biotech dalam pengadaan bahan baku pelepah Lidah Buaya dibuat perjanjian tertulis. Hal tersebut dengan harapan mendapatkan hak dan memenuhi kewajibannya masing-masing. Petani berusaha memenuhi dalam hal mutu, kuantitas, ataupun kontinuitas pasokan pelepah Lidah Buaya; sedangkan PT Kavera Biotech selalu menepati kewajibannya untuk menampung hasil panen dari petani dan membayar langsung melalui koperasi ke petani.

Dari sisi petani (KUB), kemitraan ini mampu memberikan manfaat: (1) Penguatan usaha kelembagaan petani (KUB), (2) Harga yang lebih baik, (3) Kepastian pasar atas produknya, (4) Peningkatan produksi. Melalui kemitraan ini, PT Kavera Biotech menerima manfaat: (1) Mengembangkan produk dan IRT baru, (2) Terjaminnya kontinuitas pasokan, dan (3) Memperoleh keuntungan dari hasil penjualan produk.

\section{Analisis Kelayakan Finansial}

\section{Modal Tetap}

Biaya tunai dari petani Lidah Buaya (Analisis I) dan biaya riil dari petani Lidah Buaya (Analisis II) di Kecamatan Beji, Depok membutuhkan biaya investasi yang sama, perbedaan biayanya hanya berdasarkan luas lahan. Biaya investasi yang diperlukan untuk usaha budi daya tanaman Lidah Buaya di lahan < $400 \mathrm{~m}^{2}$ membutuhkan modal tetap Rp160.000 per petani, sedangkan lahan $\geq 400 \mathrm{~m}^{2}$ membutuhkan modal tetap Rp330.000 per petani. Biaya investasi meliputi biaya peralatan pertanian, seperti cangkul, arit, parang, garpu tanah, ember, gayung, alat semprot penyiram tanah, pisau panen pelepah, dan keranjang untuk panen. Secara rinci biaya permodalan usaha dapat dilihat pada Tabel 1 dan 2.

\section{Modal Kerja}

Biaya produksi digolongkan menjadi biaya tetap dan biaya tidak tetap (variabel). Biaya tetap pada Analisis I meliputi biaya penyusutan investasi (peralatan pertanian), sedangkan biaya tetap pada Analisis II meliputi biaya sewa lahan selama satu musim tanam dan penyusutan investasi. Analisis I tidak memperhitungkan biaya sewa lahan karena yang digunakan adalah lahan pekarangan rumah, atau lahan terlantar. Untuk lahan terlantar, petani hanya meminta izin pada pemilik tanah. Analisis II memperhitungkan biaya sewa lahan sehingga dapat diketahui biaya tetap per tahun atau per satu musim tanamnya selama 5 tahun, kecuali untuk lahan dengan luas $<200$ $\mathrm{m}^{2}$ tidak ada biaya sewa lahan.

Biaya sewa lahan dengan luas $\geq 200 \mathrm{~m}^{2}$ dan $\leq 400 \mathrm{~m}^{2}$ adalah Rp500.000; luas $>400 \mathrm{~m}^{2}$ adalah Rp1.000.000. Biaya tidak tetap (variabel) pada Analisis I meliputi biaya bibit Lidah Buaya dan pupuk kandang, sedangkan biaya tidak tetap pada Analisis II meliputi bibit Lidah Buaya, pupuk kandang, dan tenaga kerja. Harga bibit Lidah Buaya ada dua macam, yaitu Rp1.000 dan Rp2.000 (bibit umur 2 bulan); sedangkan harga bibit Lidah Buaya umur 1 tahun adalah Rp30.000. Harga pupuk kandang beragam Rp500, Rp650, dan Rp750/kg. Satu tanaman Lidah Buaya membutuhkan pupuk kandang $1 \mathrm{~kg} /$ tahun yang diberikan setiap 6 bulan sekali. Pemberian pupuk kandang akan meningkatkan tinggi tanaman dan jumlah daun tanaman lidah buaya (Santosa, 2003). Untuk Analisis I, petani melakukan sendiri kegiatan budi daya tanaman Lidah Buaya mulai dari pengolahan lahan awal, menanam, memelihara, dan panen bibit, ataupun pelepah, sehingga tidak ada biaya yang dikeluarkan untuk tenaga kerja. Pada Analisis II biaya tenaga kerja dimasukkan dalam biaya tidak tetap yang dimulai dari pengolahan lahan awal, menanam, memelihara, serta panen bibit dan pelepah, kecuali untuk lahan $<50 \mathrm{~m}^{2}$ tidak dimasukkan biaya tenaga kerja.

\section{Pendapatan}

Pendapatan petani dari usaha budi daya tanaman Lidah Buaya berasal dari penjualan bibit (7\%) dan pelepah (93\%) (Tabel 3). Panen bibit Lidah Buaya setahun dua kali ( 6 bulan sekali) sebanyak dua anakan Lidah Buaya setiap panen bibit. Bibit Lidah Buaya dijual ke Koperasi Serba Usaha Aloe Vera seharga Rp1.000 per bibit. Panen pelepah Lidah Buaya pada tahun pertama hanya satu kali. Pada tahun kedua sampai tahun kelima panen pelepah Lidah Buaya 12 kali setiap tahunnya. Berat pelepah Lidah Buaya yang dihasilkan dari panen pelepah pertama $600 \mathrm{gr}$, panen pelepah kedua $800 \mathrm{gr}$, kemudian panen pelepah ketiga dan seterusnya $1 \mathrm{~kg}$. Pelepah Lidah Buaya dijual ke koperasi Rp1.000 per kg. Jumlah tanaman Lidah Buaya sampai bulan Mei 2009 sebanyak 18.315 tanaman dengan induknya sebanyak 6.105 tanaman dan anakan 12.210. 


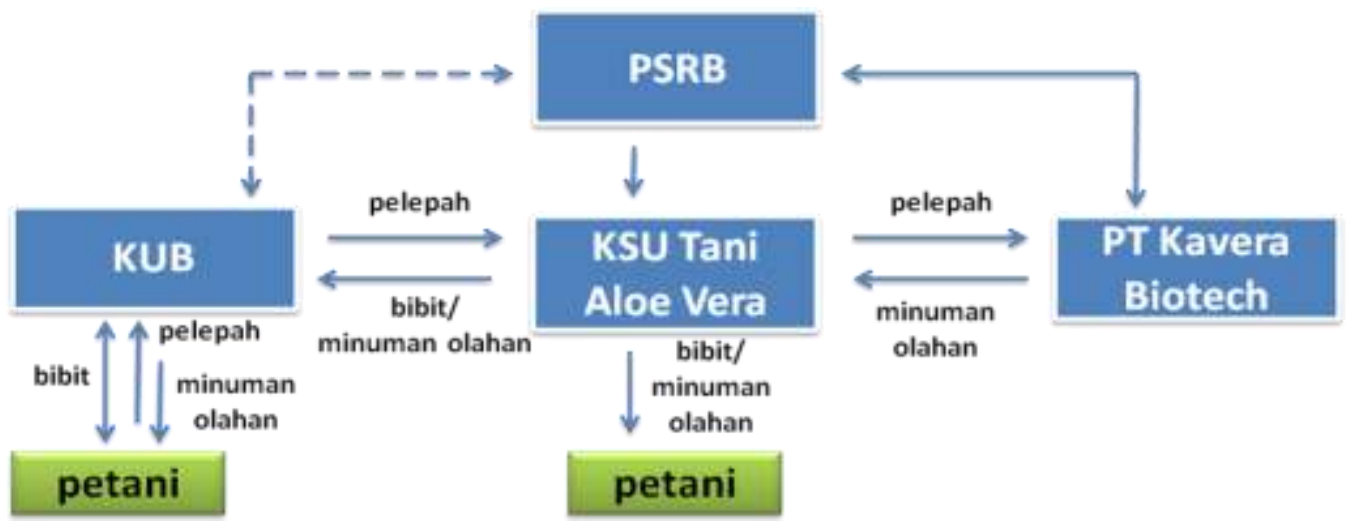

Gambar 1. Model kluster bisnis dari usaha Lidah Buaya di Depok

Tabel 1. Komponen modal tetap usaha budi daya tanaman Lidah Buaya di lahan $<400 \mathrm{~m}^{2}$

\begin{tabular}{clccccc}
\hline No. & \multicolumn{1}{c}{ Komponen } & Unit & Harga/Unit (Rp) & $\begin{array}{c}\text { Nilai } \\
(\mathbf{R p})\end{array}$ & $\begin{array}{c}\text { Umur } \\
\text { (Tahun) }\end{array}$ & $\begin{array}{c}\text { Susut/Tahun } \\
\text { (Rp) }\end{array}$ \\
\hline 1. & Cangkul & 1 & 35.000 & 35.000 & 5 & 7.000 \\
2. & Arit & 1 & 25.000 & 25.000 & 5 & 5.000 \\
3. & Garpu tanah & 1 & 15.000 & 15.000 & 5 & 3.000 \\
4. & Ember & 1 & 20.000 & 20.000 & 5 & 4.000 \\
5. & Gayung & 1 & 5.000 & 5.000 & 5 & 1.000 \\
6. & Alat semprot penyiram & 1 & 20.000 & 20.000 & 5 & 4.000 \\
& tanah & & & & \\
7. & Pisau panen pelepah & 1 & 25.000 & 25.000 & 5 & 5.000 \\
8. & Keranjang untuk panen & 1 & 15.000 & 15.000 & 5 & 3.000 \\
\hline & Total Biaya Investasi & & $\mathbf{1 6 0 . 0 0 0}$ & & $\mathbf{3 2 . 0 0 0}$ \\
\hline
\end{tabular}

Tabel 2. Komponen modal tetap usaha budi daya tanaman Lidah Buaya di lahan $\geq 400 \mathrm{~m}^{2}$

\begin{tabular}{clccccc}
\hline No. & \multicolumn{1}{c}{ Komponen } & Unit & $\begin{array}{c}\text { Harga/Unit } \\
(\mathbf{R p})\end{array}$ & $\begin{array}{c}\text { Nilai } \\
(\mathbf{R p})\end{array}$ & $\begin{array}{c}\text { Umur } \\
\text { (Tahun) }\end{array}$ & $\begin{array}{c}\text { Susut/Tahun } \\
(\mathbf{R p})\end{array}$ \\
\hline 1. & Cangkul & 2 & 35.000 & 70.000 & 5 & 14.000 \\
2. & Arit & 1 & 25.000 & 25.000 & 5 & 5.000 \\
3. & Parang & 1 & 25.000 & 25.000 & 5 & 5.000 \\
4. & Garpu tanah & 2 & 30.000 & 60.000 & 5 & 12.000 \\
5. & Ember & 2 & 20.000 & 40.000 & 5 & 8.000 \\
6. & Gayung & 2 & 5.000 & 10.000 & 5 & 2.000 \\
7. & Alat semprot penyiram & 1 & 20.000 & 20.000 & 5 & 4.000 \\
& tanah & & & & & \\
8. & Pisau panen pelepah & 2 & 25.000 & 50.000 & 5 & 10.000 \\
9. & Keranjang untuk panen & 2 & 15.000 & 30.000 & 5 & 6.000 \\
\hline
\end{tabular}

Tabel 3. Jumlah bibit dan pelepah tanaman Lidah Buaya di Kecamatan Beji, Depok

\begin{tabular}{|c|c|c|c|c|c|c|c|}
\hline No. & KUB & $\begin{array}{l}\text { Bibit per } \\
\text { tahun }\end{array}$ & $\begin{array}{l}\text { Pelepah } \\
\text { per tahun }\end{array}$ & $\begin{array}{c}\text { Bibit } \\
\text { per } \\
5 \text { tahun }\end{array}$ & $\begin{array}{c}\text { Pelepah } \\
\text { per } \\
5 \text { tahun }\end{array}$ & $\begin{array}{c}\text { Persentase } \\
\text { Bibit (\%) }\end{array}$ & $\begin{array}{c}\text { Persentase } \\
\text { Pelepah } \\
\text { (\%) }\end{array}$ \\
\hline 1. & Pondok Cina & 11.475 & 159.362 & 57.376 & 796.809 & 7 & 93 \\
\hline 2. & Kukusan & 7.648 & 106.212 & 38.240 & 531.058 & 7 & 93 \\
\hline 3. & Beji Timur & 8.666 & 120.344 & 43.328 & 601.718 & 7 & 93 \\
\hline 4. & Tanah Baru & 8.493 & 126.694 & 42.464 & 633.469 & 7 & 93 \\
\hline 5. & Beji & 1.670 & 23.198 & 8.352 & 115.988 & 7 & 93 \\
\hline 6. & Kemiri Muka & 320 & 4.444 & 1.600 & 22.220 & 7 & 93 \\
\hline
\end{tabular}




\section{Aliran Kas Usaha (Cashflow)}

Sumber investasi dari dana petani Lidah Buaya sendiri. Perhitungan aliran kas usaha budi daya Lidah Buaya berdasarkan petani lahan pekarangan rumah atau di pot dan petani lahan terlantar dari 6 KUB petani Lidah Buaya dengan Analisis I dan Analisis II selama 5 tahun dapat disimpulkan bahwa usaha budi daya Lidah Buaya dari 6 KUB di Kecamatan Beji, Depok dengan Analisis I menguntungkan, baik petani lahan pekarangan rumah, atau di pot maupun petani lahan terlantar. Hal tersebut menguntungkan karena biaya tenaga kerja tidak dimasukkan dan petani itu sendiri yang melakukan usaha budidaya Lidah Buaya mulai dari penanaman sampai pemanenan. Selain itu, tidak ada biaya sewa lahan, karena dilakukan di lahan pekarangan rumah sendiri, atau lahan terlantar yang tidak produktif kemudian dimanfaatkan oleh para petani tersebut.

Usaha budi daya Lidah Buaya dengan Analisis II menunjukkan bahwa 6 KUB di Kecamatan Beji, Depok menguntungkan, walaupun keuntungan KUB di Kemiri Muka dengan penanaman di lahan pekarangan rumah atau di pot tidak terlalu menjanjikan. Hal tersebut karena biaya tenaga kerja dimasukkan dalam Analisis II, sehingga lebih banyak pengeluaran daripada pendapatan. Oleh karena itu, untuk petani yang menanam di lahan pekarangan rumah, atau di pot sebaiknya melakukan sendiri usaha budi daya Lidah Buaya, apalagi bila jumlah tanaman yang belum banyak, seperti petani di KUB Kemiri Muka yang baru menanam 50 tanaman di lahan pekarangan rumah, atau di pot.

Hasil perhitungan aliran kas usaha budi daya Lidah Buaya berdasarkan pengelompokan penanaman pada semua skala penanaman dengan Analisis I dan Analisis II menguntungkan, baik petani lahan pekarangan rumah atau di pot, maupun petani lahan terlantar.

\section{Analisis Kelayakan Finansial}

Analisis kelayakan finansial dalam kajian ini adalah menggunakan PBP, NPV, BCR, IRR, dan BEP. Data yang digunakan adalah data pendapatan bersih yang diperoleh dengan cara mengurangkan arus kas masuk dengan arus kas keluar. Tingkat diskonto yang digunakan adalah $20 \%$ sebagai rataan suku bunga deposito bank umum pada saat kajian.

Usaha budi daya Lidah Buaya di KUB Tanah Baru pada Analisis I dan II menunjukkan nilai PBP yang paling cepat mengembalikan investasinya (2,95 bulan dan 6,30 bulan). Petani lahan terlantar dari KUB Tanah Baru pada Analisis I dan II dengan nilai PBP paling cepat (1,42 dan 5,35 bulan), karena jumlah tanamannya (1.000 tanaman per petani) sudah dapat menutupi modal. Untuk petani lahan pekarangan rumah atau di pot dengan Analisis II dari petani KUB Kemiri Muka (50 tanaman per petani), nilai PBP 69,24 bulan. Hal ini terkait dengan jumlah tanaman dan biaya yang dikeluarkan petani pekarangan rumah, atau di pot lebih besar dari pendapatannya. Untuk itu, perlu usaha penambahan jumlah tanaman Lidah Buaya pada setiap petani pekarangan atau menghilangkan biaya tenaga kerja dan sewa lahan.

Nilai NPV yang dihasilkan dari usaha budi daya Lidah Buaya di KUB Pondok Cina pada Analisis I adalah yang terbesar, dengan lama usaha lima tahun, yaitu Rp51.633.612. Begitu pula pada Analisis II yang terbesar di KUB Tanah Baru, yaitu Rp17.468.325. Begitu pula untuk NPV dengan Analisis I dan II pada petani lahan pekarangan rumah, atau di pot dari KUB Pondok Cina menunjukkan nilai tertinggi (Rp8.848.051 dan Rp2.143.573), sedangkan NPV dengan Analisis I dan II yang tertinggi pada petani lahan terlantar dari KUB Tanah Baru, adalah Rp29.389.360 dan Rp13.073.720.

Hasil perhitungan BCR usaha budi daya Lidah Buaya diperoleh nilai tertinggi 53 pada Analisis I dari KUB Pondok Cina, artinya biaya yang dikeluarkan oleh KUB 1 satuan akan menghasilkan tingkat pendapatan 53 satuan. Untuk Analisis II diperoleh nilai tertinggi 20 pada KUB Tanah Baru. BCR $<1$ terlihat pada KUB Kemiri Muka dari petani lahan pekarangan atau di pot dengan Analisis II, artinya usaha budi daya Lidah Buaya tidak layak dilaksanakan dalam 5 tahun (Gaspersz, 2005).

Penilaian IRR dari KUB di Kecamatan Beji menghasilkan nilai IRR lebih tinggi dibandingkan dengan suku bunga deposito bank (DF 20\%) pada saat kajian, sehingga usaha budi daya Lidah Buaya layak dilaksanakan (Gaspersz, 2005), kecuali petani lahan pekarangan rumah, atau di pot dari KUB Kemiri Muka dengan Analisis II.

Nilai BEP yang diperoleh dibuat dalam satuan, yaitu jumlah bibit (7\%) dan pelepah $(93 \%)$, karena produk yang dihasilkan budi daya Lidah Buaya adalah bibit tanaman Lidah Buaya dan pelepah Lidah Buaya. Nilai BEP yang diperoleh beragam pada masing-masing KUB di Kecamatan Beji, Depok, yaitu antara 161-1.026 satuan untuk Analisis I. Untuk Analisis II, nilai BEP antara 1.169-10.796 satuan. Nilai BEP untuk petani lahan pekarangan atau di pot dengan Analisis I dan II 161-237 satuan dan 168-8.526 satuan. Untuk petani lahan terlantar dengan analisis I dan II adalah 334-335 satuan dan 5.8515.929 satuan.

Usaha budi daya Lidah Buaya berdasarkan pengelompokan penanaman dari petani lahan pekarangan rumah atau di pot (skala kecil $(<100$ tanaman), skala sedang (100-199 tanaman), dan skala besar (200-399 tanaman) dan petani di lahan terlantar skala sempit (300-399 tanaman), skala sedang (400-499 tanaman), dan skala luas (> 500 tanaman) dengan Analisis I dan Analisis II selama 5 tahun menunjukkan pada semua skala penanaman, baik di lahan pekarangan rumah atau di pot, maupun di lahan terlantar layak untuk dilakukan. 


\section{Analisis Strategi Pengembangan Usaha}

\section{Analisis Matriks EFE}

Peluang utama yang diakui dalam pengembangan usaha Lidah Buaya dengan pola kemitraan adalah permintaan akan bahan baku pelepah Lidah Buaya yang terus meningkat (skor 0,3856 ). Adanya pola kemitraan antara petani dan industri pengolahan Lidah Buaya (skor 0,3737) menjadi daya tarik dan peluang bagi masyarakat yang berminat untuk berusaha dalam pembudidayaan Lidah Buaya di Kecamatan Beji, Depok.

Ancaman utama dalam pengembangan usaha Lidah Buaya pola kemitraan adalah kurangnya peranserta pemerintah daerah (skor 0,0721 ), apalagi bila sudah semakin berkembang usaha Lidah Buaya di Kecamatan Beji, Depok nanti (Tabel 4).

\section{Analisis Matriks IFE}

Berdasarkan hasil perhitungan pada Tabel 10, mutu produk pelepah Lidah Buaya lebih baik diakui sebagai faktor kekuatan paling penting yang dimiliki usaha Lidah Buaya dengan pola kemitraan dalam pengembangan usahanya (skor 0,4909 ). Kelemahan utama dalam pengembangan usaha Lidah Buaya dengan pola kemitraan adalah manajemen KUB belum mandiri, dengan skor 0,0711 (Tabel 5)).

Selanjutnya, hasil evaluasi matriks IFE digabungkan dengan hasil evaluasi matriks EFE menggunakan model Matriks SWOT dan Matriks IE. Pada tahapan ini dipetakan posisi usaha Lidah Buaya dengan pola kemitraan dalam suatu diagram untuk mempermudah perumusan alternatif strategi unit usaha.

Tabel 4. Perhitungan matriks EFE usaha Lidah Buaya di Kecamatan Beji, Depok

\begin{tabular}{|c|c|c|c|c|}
\hline & Faktor Strategi Eksternal & $\begin{array}{l}\text { Bobot } \\
\text { (a) }\end{array}$ & $\begin{array}{l}\text { Rating } \\
\text { (b) }\end{array}$ & $\begin{array}{l}\text { Skor } \\
\text { (axb) }\end{array}$ \\
\hline \multicolumn{5}{|c|}{ Peluang (A) } \\
\hline A & Permintaan akan bahan baku pelepah Lidah Buaya meningkat & 0,0964 & 4 & 0,3856 \\
\hline B & Jaminan jaringan pemasaran & 0,0897 & 4 & 0,3588 \\
\hline C & $\begin{array}{l}\text { Adanya pola kemitraan antara petani dan industri pengolahan Lidah } \\
\text { Buaya }\end{array}$ & 0,0934 & 4 & 0,3737 \\
\hline $\mathbf{D}$ & Harga bibit dan pelepah Lidah Buaya cukup menarik bagi petani & 0,0897 & 4 & 0,3588 \\
\hline $\mathbf{E}$ & Kondisi sosial masyarakat dan lingkungan yang kondusif & 0,0822 & 4 & 0,3289 \\
\hline $\mathbf{F}$ & $\begin{array}{l}\text { Hama, penyakit, dan gangguan alam pada tanaman Lidah Buaya } \\
\text { tidak mengganggu }\end{array}$ & 0,0822 & 3 & 0,2466 \\
\hline G & $\begin{array}{l}\text { Adanya lahan terlantar yang dapat dimanfaatkan untuk budi daya } \\
\text { Lidah Buaya }\end{array}$ & 0,0972 & 3,4 & 0,3304 \\
\hline \multicolumn{5}{|c|}{ Ancaman (B) } \\
\hline $\mathbf{H}$ & Produk merupakan kebutuhan sekunder & 0,0635 & 2 & 0,1271 \\
\hline I & Kurang sosialisasi manfaat Lidah Buaya & 0,0934 & 1,6 & 0,1495 \\
\hline $\mathbf{J}$ & Teknologi dari usaha budi daya Lidah Buaya terbatas & 0,0710 & 2 & 0,1420 \\
\hline K & Kurangnya peran serta pemerintah daerah & 0,0515 & 1,4 & 0,0721 \\
\hline \multirow[t]{2}{*}{$\mathbf{L}$} & Pemasok seperti pupuk organik terbatas & 0,0897 & 1 & 0,0897 \\
\hline & Total $(A+B)$ & 1,0000 & & 2,9631 \\
\hline
\end{tabular}

Tabel 5. Perhitungan matriks IFE usaha Lidah Buaya di Kecamatan Beji, Depok

\begin{tabular}{lccc}
\hline \multicolumn{1}{c}{ Faktor Strategi Internal } & $\begin{array}{c}\text { Bobot } \\
(\mathbf{a})\end{array}$ & $\begin{array}{c}\text { Rating } \\
(\mathbf{b})\end{array}$ & $\begin{array}{c}\text { Skor } \\
(\mathbf{a x b})\end{array}$ \\
\hline Kekuatan (A) & 0,1227 & 4 & 0,4909 \\
A Mutu produk pelepah Lidah Buaya lebih baik & 0,1114 & 3,6 & 0,4011 \\
B $\quad$ Tanaman Lidah Buaya mudah dipelihara & 0,1082 & 3,6 & 0,3896 \\
C Produksi bibit yang cepat dan bernilai jual & 0,1082 & 3,6 & 0,3896 \\
D $\quad$ Biaya produksi tidak besar & 0,1082 & 3,6 & 0,3896 \\
E Tingkat pengembalian modal petani Lidah Buaya cepat & 0,1105 & 4 & 0,4419 \\
F $\quad$ Tempat usaha sesuai untuk budi daya Lidah Buaya & & & \\
Kelemahan (B) & 0,0759 & 1,8 & 0,1366 \\
G Sarana petani Lidah Buaya kurang memadai & 0,0711 & 1,6 & 0,1138 \\
H Produksi pelepah Lidah Buaya masih rendah & 0.0711 & 1 & 0,0711 \\
I Manajemen KUB belum mandiri & 0,1126 & 1 & 0,1126 \\
J Lahan yang dimiliki anggota KUB terbatas & $\mathbf{1 , 0 0 0 0}$ & & $\mathbf{2 , 9 3 6 8}$ \\
\hline$\quad$ Total (A+B) & &
\end{tabular}




\section{Analisis Matriks SWOT}

Penyusunan formulasi strategi dilakukan dengan mengkombinasikan berbagai faktor yang telah diidentifikasi dan dikelompokkan. Hasil formulasi dikelompokkan menjadi empat kelompok formulasi strategi (Rangkuti, 2004) yang terdiri dari strategi Kekuatan-Peluang (S-O), strategi Kekuatan-Ancaman (S-T), strategi KelemahanPeluang (W-O) dan strategi Kelemahan-Ancaman (W-T), seperti yang dimuat dalam Gambar 2.

\section{Matriks IE}

Matriks IE disusun untuk mengetahui strategi apa yang sebaiknya digunakan. Untuk menentukan strategi tersebut, dipetakan skor rataan dari matriks IFE $(2,9368)$ dan EFE (2,9631). Hasil pemetaan dalam matriks, posisi usaha Lidah Buaya dengan pola kemitraan berada pada kuadran lima yang merupakan pertumbuhan. Pada sel ini, strategi pertumbuhan melalui integrasi horizontal, yaitu suatu kegiatan untuk memperluas perusahaan dengan cara membangun di lokasi lain dan meningkatkan jenis produk serta jasa.

Usaha Lidah Buaya dengan pola kemitraan di Kecamatan Beji, Depok dapat mengembangkan usahanya dengan meningkatkan kelembagaan petani Lidah Buaya (KUB) sebagai pemasok pelepah Lidah Buaya dengan dibina dan dilatih untuk meningkatkan produksinya melalui penyediaan sarana produksi, fasilitasi sarana dan prasarana produksi, seperti transportasi ketika panen bibit ataupun panen pelepah Lidah Buaya, sehingga ketersediaan pelepah selalu tersedia. Selain itu, dapat pengembangan usaha dengan mendirikan industri pengolahan Lidah Buaya dalam skala rumah tangga dalam satu kawasan. Hal ini merupakan cara terbaik bagi usaha yang kuat dalam rangka meningkatkan keunggulan kompetitif (competitive advantage) di dalam industri yang atraktif.

\begin{tabular}{|c|c|c|}
\hline Faktor Eksternal & $\begin{array}{l}\text { Kekuatan (S) } \\
\text { 1. Mutu produk pelepah Lidah Buaya lebih } \\
\text { baik } \\
\text { 2. Tempat usaha sesuai untuk budidaya } \\
\text { Lidah Buaya } \\
\text { 3. Tanaman Lidah Buaya mudah dipelihara } \\
\text { 4. Produksi bibit yang cepat dan bernilai } \\
\text { jual } \\
\text { 5. Biaya produksi tidak besar } \\
\text { 6. Tingkat pengembalian modal petani } \\
\text { Lidah Buaya cepat }\end{array}$ & $\begin{array}{l}\quad \text { Kelemahan (W) } \\
\text { 1. Manajemen KUB belum } \\
\text { mandiri } \\
\text { 2. Lahan yang dimiliki anggota } \\
\text { KUB terbatas } \\
\text { 3. Produksi pelepah Lidah Buaya } \\
\text { masih rendah } \\
\text { 4. Sarana petani Lidah Buaya } \\
\text { kurang memadai }\end{array}$ \\
\hline Peluang (0) & Strategi SO (agresif) & Strategi WO (diversifikasi) \\
\hline $\begin{array}{l}\text { 1. Permintaan akan bahan baku } \\
\text { pelepah Lidah Buaya meningkat } \\
\text { 2. Adanya pola kemitraan antara } \\
\text { petani dan industri pengolahan } \\
\text { Lidah Buaya } \\
\text { 3. Jaminan jaringan pemasaran } \\
\text { 4. Harga bibit dan pelepah Lidah } \\
\text { Buaya cukup menarik bagi petani } \\
\text { 5. Adanya lahan terlantar yang dapat } \\
\text { dimanfaatkan untuk budidaya Lidah } \\
\text { Buaya } \\
\text { 6. Kondisi sosial masyarakat dan } \\
\text { lingkungan yang kondusif } \\
\text { 7. Hama, penyakit, dan gangguan } \\
\text { alam pada tanaman Lidah Buaya } \\
\text { tidak mengganggu }\end{array}$ & $\begin{array}{l}\text { 1. Membangun kemitraan antara petani } \\
\text { (KUB) dan industri pengolahan Lidah } \\
\text { Buaya dengan tetap mempertahankan } \\
\text { mutu produk (S1,S2,S3,O2,O3,O4,O6) } \\
\text { 2. Meningkatkan produktivitas dalam } \\
\text { memanfaatkan permintaan bahan baku } \\
\text { Lidah Buaya yang semakin meningkat } \\
\text { (S1, S2, S3, S4, S5, S6, O1, O4, O5, } \\
\text { O7) } \\
\text { 3. Mengembangkan budi daya Lidah Buaya } \\
\text { dalam skala rumah tangga dengan } \\
\text { dukungan dari tempat yang strategis, } \\
\text { serta kondisi sosial masyarakat dan } \\
\text { lingkungan kondusif (S2, S3, S4, S5, S6, } \\
\text { O1, O2, O3, O4, O5, O6) }\end{array}$ & $\begin{array}{l}\text { 1. Memanfaatkan lahan terlantar } \\
\text { untuk budidaya Lidah Buaya, } \\
\text { sehingga dapat meningkatkan } \\
\text { produksi pelepah Lidah Buaya } \\
\text { karena adanya jaminan } \\
\text { pemasaran (W2, W3, W4, O1, } \\
\text { O3, O4, O5, O6, O7) } \\
\text { 2. Meningkatkan kemandirian } \\
\text { manajemen KUB yang } \\
\text { didukung kondisi sosial } \\
\text { masyarakat dan lingkungan } \\
\text { kondusif, sehingga dapat } \\
\text { meningkatkan produksi (W1, } \\
\text { W3,W4, O1, O2, O3, O4, O6, } \\
\text { O7) }\end{array}$ \\
\hline Ancaman $(T)$ & Strategi ST (diferensiasi) & Strategi WT (defensif) \\
\hline $\begin{array}{l}\text { 1. Kurangnya peranserta pemerintah } \\
\text { daerah } \\
\text { 2. Pemasok seperti pupuk organik } \\
\text { terbatas } \\
\text { 3. Produk merupakan kebutuhan } \\
\text { sekunder } \\
\text { 4. Teknologi dari usaha budidaya } \\
\text { Lidah Buaya terbatas } \\
\text { 5. Kurang sosialisasi manfaat Lidah } \\
\text { Buaya }\end{array}$ & $\begin{array}{l}\text { 1. Meningkatkan peran serta pemerintah } \\
\text { daerah untuk mendukung bahwa tempat } \\
\text { usaha budidaya Lidah Buaya adalah } \\
\text { strategis yang didukung dengan biaya } \\
\text { produksi tidak besar dan pengembalian } \\
\text { modal petani Lidah Buaya cepat kembali } \\
\text { (S2, S3, S4, S5, S6, T1, T4) } \\
\text { 2. Meningkatkan informasi tentang manfaat } \\
\text { Lidah Buaya dalam mengembangkan } \\
\text { budi daya Lidah Buaya di Beji, Depok } \\
\text { (S1, S2, S3, S4, S5, S6, T4, T5) }\end{array}$ & $\begin{array}{l}\text { 1. Aktif menjalin kerja sama } \\
\text { dengan institusi terkait dalam } \\
\text { menghadapi permasalahan } \\
\text { Lidah Buaya (W1, W2, W3, W4, } \\
\text { T1, T2, T3, T4, T5) } \\
\text { 2. Meningkatkan kemampuan } \\
\text { manajemen KUB melalui } \\
\text { pelatihan dan magang (W1, T1, } \\
\text { T2, T3) } \\
\text { 3. Mendorong anggota KUB untuk } \\
\text { meningkatkan sistem usaha } \\
\text { tani dan pendukungnya (W1, } \\
\text { W2, W3, W4, T1, T2, T3, T4) }\end{array}$ \\
\hline
\end{tabular}




\section{Pemilihan Alternatif Strategi}

Pemilihan alternatif strategi dilakukan dengan memberikan bobot (1-4) pada setiap unsur SWOT yang telah diidentifikasi sesuai tingkat kepentingannya (Tabel 6). Setelah pembobotan, langkah selanjutnya menentukan skor kepentingan dari setiap alternatif strategi yang diperoleh dalam analisis SWOT berdasarkan jumlah akumulasi keterkaitan antara unsur SWOT yang menghasilkan strategi tersebut (Tabel 7). Dari hasil penjumlahan itu, masing-masing alternatif strategi diberi peringkat (ranking) yang merupakan urutan strategi terbaik berdasarkan kondisi usaha saat ini. Dari 10 alternatif strategi yang diperoleh dalam analisis SWOT dipilih alternatif strategi untuk diimplementasikan dari 3 peringkat tertinggi.

Tabel 6. Tingkat kepentingan alternatif strategi analisis SWOT

\begin{tabular}{|c|c|}
\hline SWOT & $\begin{array}{l}\text { Pering- } \\
\text { kat }\end{array}$ \\
\hline Kekuatan (S) & 23 \\
\hline $\begin{array}{l}\text { S1 Mutu produk pelepah Lidah Buaya lebih } \\
\text { baik }\end{array}$ & 4 \\
\hline $\begin{array}{l}\text { S2 Tempat usaha sesuai untuk budi daya } \\
\text { Lidah Buaya }\end{array}$ & 4 \\
\hline S3 Tanaman Lidah Buaya mudah dipelihara & 4 \\
\hline S4 Produksi bibit yang cepat dan bernilai jual & 4 \\
\hline S5 Biaya produksi tidak besar & 3,4 \\
\hline $\begin{array}{l}\text { S6 Tingkat pengembalian modal petani Lidah } \\
\text { Buaya cepat }\end{array}$ & 3,6 \\
\hline Kelemahan (W) & 6 \\
\hline W1 Manajemen KUB belum mandiri & 1,4 \\
\hline W2 Lahan yang dimiliki anggota KUB terbatas & 1,4 \\
\hline $\begin{array}{l}\text { W3 Produksi pelepah Lidah Buaya masih } \\
\text { rendah }\end{array}$ & 2 \\
\hline $\begin{array}{l}\text { W4 Sarana petani Lidah Buaya kurang } \\
\text { memadai }\end{array}$ & 1 \\
\hline Peluang (0) & 27 \\
\hline $\begin{array}{l}\text { O1 Permintaan akan bahan baku pelepah } \\
\text { Lidah Buaya meningkat }\end{array}$ & 4 \\
\hline $\begin{array}{l}\text { O2 Adanya pola kemitraan antara petani dan } \\
\text { industri pengolahan Lidah Buaya }\end{array}$ & 4 \\
\hline O3 Jaminan jaringan pemasaran & 4 \\
\hline $\begin{array}{l}\text { O4 Harga bibit dan pelepah Lidah Buaya } \\
\text { cukup menarik bagi petani }\end{array}$ & 4 \\
\hline $\begin{array}{l}\text { O5 Adanya lahan terlantar yang dapat } \\
\text { dimanfaatkan untuk budidaya Lidah Buaya }\end{array}$ & 4 \\
\hline $\begin{array}{l}\text { O6 Kondisi sosial masyarakat dan lingkungan } \\
\text { kondusif }\end{array}$ & 4 \\
\hline $\begin{array}{l}\text { O7 Hama, penyakit, dan gangguan alam pada } \\
\text { tanaman Lidah Buaya tidak mengganggu }\end{array}$ & 3 \\
\hline Ancaman (T) & 10 \\
\hline T1 Kurangnya peranserta pemerintah daerah & 2 \\
\hline T2 Pemasok seperti pupuk organik terbatas & 2 \\
\hline T3 Produk merupakan kebutuhan sekunder & 2 \\
\hline $\begin{array}{l}\text { T4 Teknologi dari usaha budi daya Lidah } \\
\text { Buaya terbatas }\end{array}$ & 2 \\
\hline T5 Kurang sosialisasi manfaat Lidah Buaya & 2 \\
\hline
\end{tabular}

Berdasarkan analisis tersebut, strategi yang paling efektif dilakukan sebagai berikut:

a. Mengembangkan budi daya Lidah Buaya dalam skala rumah tangga dengan dukungan dari tempat yang strategis serta kondisi sosial masyarakat dan lingkungan yang kondusif.

b. Meningkatkan produktivitas dalam memanfaatkan permintaan bahan baku Lidah Buaya yang semakin meningkat.

c. Membangun kemitraan antara petani (KUB) dan industri pengolahan Lidah Buaya dengan tetap mempertahankan mutu produk.

\section{Implementasi Strategi}

Hasil analisis QSPM menunjukkan bahwa strategi kedua tentang meningkatkan produktivitas dalam memanfaatkan permintaan bahan baku memiliki nilai tertinggi $(7,258)$. Strategi tersebut dapat diimplementasi pada aspek meningkatkan usaha tani dan pendukungnya secara efektif dan efisien, serta meningkatkan kapasitas produksi pelepah Lidah Buaya. Peningkatan produksi dapat dilakukan dengan penambahan luas tanam dengan mengajak peranserta masyarakat untuk menanam dalam skala rumah tangga yang memanfaatkan lahan pekarangan rumah atau di pot dan lahan terlantar. Masalah hama, penyakit, dan gangguan alam pada tanaman Lidah Buaya, serta kemampuan petani yang terbatas perlu diperhatikan dan ditanggulangi dengan diadakan penyuluhan pertanian dan pertemuan rutin di tingkat KUB, agar produksi pelepah Lidah Buaya dapat terus meningkat.

\section{KESIMPULAN}

Usaha kemitraan antara petani (mitra binaan plasma KUB) dan industri pengolahan Lidah Buaya di Kecamatan Beji, Depok terbentuk dalam suatu model kluster bisnis dengan adanya KSU Tani Aloe Vera dan Pusat Sinergi Riset Bisnis (PSRB) sebagai mediator antara petani dan industri pengolahan Lidah Buaya.

Usaha Lidah Buaya dengan pola kemitraan berdasarkan Analisis I layak dilaksanakan di 6 KUB (Pondok Cina, Kukusan, Beji Timur, Tanah Baru, Beji dan Kemiri Muka). Berdasarkan Analisis II layak dilaksanakan di 5 KUB (Pondok Cina, Kukusan, Beji Timur, Tanah Baru, dan Beji). Usaha Lidah Buaya pada petani lahan pekarangan rumah atau di pot dengan penanaman skala kecil (< 100 tanaman), skala sedang (100-199 tanaman), dan skala besar (200-399 tanaman) serta petani lahan terlantar dengan penanaman skala sempit (300-399 tanaman), skala sedang (400-499 tanaman), dan skala luas (> 500 tanaman) berdasarkan Analisis I dan II layak dilaksanakan. Dari analisis diperoleh alternatif strategi terbaik, yaitu meningkatkan produktivitas dalam memanfaatkan permintaan bahan baku Lidah Buaya yang semakin meningkat. Implemen-tasi strategi dilakukan dengan meningkatkan usaha tani dan pendukungnya secara efektif dan efisien. 
Tabel 7. Penentuan alternatif strategi terbaik pada usaha Lidah Buaya di Kecamatan Beji, Depok

\begin{tabular}{|c|c|c|c|}
\hline Alternatif Strategi SWOT & Keterkaitan & Kepentingan & Peringkat \\
\hline \multicolumn{4}{|l|}{ Strategi $S-O$} \\
\hline $\begin{array}{l}\text { 1. Membangun kemitraan antara petani (KUB) dan industri } \\
\text { pengolahan Lidah Buaya, dengan tetap mempertahankan } \\
\text { mutu produk. }\end{array}$ & $\begin{array}{l}(\mathrm{S} 1, \mathrm{~S} 2, \mathrm{~S} 3, \mathrm{O} 2 \\
\mathrm{O} 3, \mathrm{O} 4, \mathrm{O} 6)\end{array}$ & 28 & 3 \\
\hline $\begin{array}{l}\text { 2. Meningkatkan produksi dan produktivitas dalam } \\
\text { memanfaatkan permintaan bahan baku Lidah Buaya yang } \\
\text { semakin meningkat. }\end{array}$ & $\begin{array}{l}(\mathrm{S} 1, \mathrm{~S} 2, \mathrm{~S} 3, \mathrm{~S} 4 \\
\mathrm{S} 5, \mathrm{~S} 6, \mathrm{O} 1, \mathrm{O} 4 \\
\mathrm{O} 5, \mathrm{O} 7)\end{array}$ & 38 & 2 \\
\hline $\begin{array}{l}\text { 3. Mengembangkan budidaya Lidah Buaya dalam skala } \\
\text { rumah tangga dengan dukungan dari tempat yang } \\
\text { strategik serta kondisi sosial masyarakat dan lingkungan } \\
\text { kondusif. }\end{array}$ & $\begin{array}{l}(\mathrm{S} 2, \mathrm{~S} 3, \mathrm{~S} 4, \mathrm{~S} 5 \\
\mathrm{S} 6, \mathrm{O} 1, \mathrm{O} 2, \mathrm{O} 3 \\
\mathrm{O} 4, \mathrm{O} 5, \mathrm{O} 6)\end{array}$ & 43 & 1 \\
\hline \multicolumn{4}{|l|}{ Strategi $S-T$} \\
\hline $\begin{array}{l}\text { 1. Meningkatkan peranserta pemerintah daerah untuk } \\
\text { mendukung bahwa tempat usaha budidaya Lidah Buaya } \\
\text { adalah strategik yang didukung dengan biaya produksi } \\
\text { tidak besar dan pengembalian modal petani Lidah Buaya } \\
\text { cepat kembali. }\end{array}$ & $\begin{array}{l}(\mathrm{S} 2, \mathrm{~S} 3, \mathrm{~S} 4, \mathrm{~S} 5 \\
\quad \mathrm{S} 6, \mathrm{~T} 1, \mathrm{~T} 4)\end{array}$ & 22 & 7 \\
\hline $\begin{array}{l}\text { 2. Meningkatkan informasi tentang manfaat Lidah Buaya, } \\
\text { dalam mengembangkan budidaya Lidah Buaya di Beji, } \\
\text { Depok. }\end{array}$ & $\begin{array}{l}(\mathrm{S} 1, \mathrm{~S} 2, \mathrm{~S} 3, \mathrm{~S} 4 \\
\mathrm{S} 5, \mathrm{~S} 6, \mathrm{~T} 4, \mathrm{~T} 5)\end{array}$ & 26 & 6 \\
\hline \multicolumn{4}{|l|}{ Strategi $W-O$} \\
\hline $\begin{array}{l}\text { 1. Memanfaatkan lahan terlantar untuk budidaya Lidah } \\
\text { Buaya sehingga dapat meningkatkan produksi } \\
\text { pelepahLidah Buaya, karena adanya jaminan pemasaran. }\end{array}$ & $\begin{array}{l}(\mathrm{W} 2, \mathrm{~W} 3, \mathrm{~W} 4 \\
\mathrm{O} 1, \mathrm{O} 3, \mathrm{O} 4, \mathrm{O} \\
\mathrm{O} 6, \mathrm{O})\end{array}$ & 27,4 & 4 \\
\hline $\begin{array}{l}\text { 2. Meningkatkan kemandirian manajemen KUB yang } \\
\text { didukung kondisi sosial masyarakat dan lingkungan } \\
\text { kondusif, sehingga dapat meningkatkan produksi. }\end{array}$ & $\begin{array}{l}(\mathrm{W} 1, \mathrm{~W} 3, \mathrm{~W} 4 \\
\mathrm{O} 1, \mathrm{O} 2, \mathrm{O} 3, \mathrm{O} 4 \\
\mathrm{O} 6, \mathrm{O})\end{array}$ & 27,4 & 5 \\
\hline \multicolumn{4}{|l|}{ Strategi $W-T$} \\
\hline $\begin{array}{l}\text { 1. Aktif menjalin kerja sama dengan institusi terkait dalam } \\
\text { menghadapi permasalahan Lidah Buaya. }\end{array}$ & $\begin{array}{c}(\mathrm{W} 1, \mathrm{~W} 2, \mathrm{~W} 3 \\
\mathrm{W} 4, \mathrm{~T} 1, \mathrm{~T} 2, \mathrm{~T} 3 \\
\mathrm{~T} 4, \mathrm{~T} 5)\end{array}$ & 15,8 & 8 \\
\hline $\begin{array}{l}\text { 2. Meningkatkan kemampuan manajemen KUB melalui } \\
\text { pelatihan dan magang. }\end{array}$ & (W1, T1, T2, T3) & 8,4 & 10 \\
\hline $\begin{array}{l}\text { 3. Mendorong anggota KUB untuk meningkatkan sistem } \\
\text { usaha tani dan pendukungnya. }\end{array}$ & $\begin{array}{c}(\mathrm{W} 1, \mathrm{~W} 2, \mathrm{~W} 3 \\
\mathrm{W} 4, \mathrm{~T} 1, \mathrm{~T} 2, \mathrm{~T} \\
\mathrm{~T} 4)\end{array}$ & 13,8 & 9 \\
\hline
\end{tabular}

\section{DAFTAR PUSTAKA}

Adi, M.K. 2007. Analisis Usaha Kecil dan Menengah. Penerbit Andi, Yogyakarta.

Asngad, A. 2008. Pemanfaatan Lidah Buaya (Aloe vera) Menjadi Produk Makanan Berserat Dengan Penambahan Berbagai Jenis Gula. Jurnal Penelitian Sains dan Teknologi, 9(2): 144-155.

David, F.R. 2005. Manajemen Strategis. Penerbit Salemba Empat, Jakarta.

Funawanthi, I. 2002. Khasiat dan Manfaat Lidah Buaya Si Tanaman Ajaib. Balai Pengkajian Bioteknologi. BPPT dengan Agro Media Pustaka, Jakarta.
Gaspersz, V. 2005. Ekonomi Manajerial. Pembuatan Keputusan Bisnis. PT Gramedia Pustaka Utama, Jakarta.

Hafsah, M.J. 2000. Kemitraan Usaha. Konsepsi dan Strategi. Pustaka Sinar Harapan, Jakarta.

Hubeis, M. 2009. Prospek Usaha Kecil Dalam Wadah Inkubator Bisnis. PT Ghalia Indonesia, Bogor.

Nurtiyani, E. 2008. Pengembangan Sumber Daya Lahan dan Tanaman Pangan Berbasis Masyarakat. Pusat Sinergi Riset dan Bisnis FMIPA-UI, Depok.

Rangkuti, F. 2004. Analisis SWOT Teknik Membedah Kasus Bisnis. Reorientasi Konsep Perencanaan Strategis untuk 
Menghadapi Abad 21. PT Gramedia Pustaka Utama, Jakarta.

Padmarsari, F.X.W., Dewi Y.S.K. dan Rahayuni T. 2006. Aktivitas antioksidan dan kemampuan pemerangkapan radikal bebas pada eksternal Aloe vera. Journal MIPA 35(1):101-113.

Ramadhia, M., S. Kumalaningsih, dan I. Santoso. 2012. Pembuatan Tepung Lidah Buaya (Aloe vera L.) dengan Metode Foam-Mat Drying. Jurnal Teknologi Pertanian, 13(2): 125-137.

Santosa, E. 2003. Pengaruh Jenis Pupuk Organik dan Mulsa terhadap Pertumbuhan Tanaman Lidah Buaya (Aloe vera Mill.). Buletin Agronomi, 31(3): 120-125.

Sasli, I., S. Yahya, Sudradjat, Y. Setiadi dan Sudarsono. 2008. Perbaikan Pertumbuhan dan Kualitas Tanaman Lidah Buaya di Tanah Gambut dengan Aplikasi Mikoriza Arbuskula dan Pemupukan. Buletin Agronomi, 36(3): 248-254.

Sulaeman, S. 2009. Model pengembangan agribisnis komoditi lidah buaya (Aloe vera). www.smecda.com [8 Januari 2009].

Sumodiningrat, G. 2000. Pembangunan Ekonomi melalui Pengembangan Pertanian. PT Bina Rena Pariwara, Jakarta.

Syafa'at, N., Simatupang P., Mardianto S. dan Khudori. 2005. Pertanian Menjawab Tantangan Ekonomi Nasional. Argumentasi Teoritis, Faktual, dan Strategi Kebijakan. Lapera Pustaka Utama, Yogyakarta.

Wahjono, E. dan Koesnandar. 2002. Mengebunkan Lidah Buaya secara Intensif. PT AgroMedia Pustaka, Jakarta. 